\title{
Effects of diesel and lubricant oils on Antarctic benthic microbial communities over five years
}

\author{
Shane M. Powell ${ }^{1,2, *}$, Jonathan S. Stark ${ }^{1}$, Ian Snape ${ }^{1}$, Ellen N. M. Woolfenden ${ }^{3}$, \\ John P. Bowman ${ }^{2}$, Martin J. Riddle ${ }^{1}$
}

\begin{abstract}
${ }^{1}$ Australian Antarctic Division, Department of Environment, Water, Heritage and the Arts, Kingston, Tasmania 7050, Australia ${ }^{2}$ Tasmanian Institute of Agricultural Science, University of Tasmania, Hobart, Tasmania 7001, Australia ${ }^{3}$ Department of Earth and Planetary Sciences, Macquarie University, Sydney, New South Wales 2019, Australia
\end{abstract}

\begin{abstract}
A 5 yr field experiment was carried out comparing the effects of Special Antarctic Blend (SAB) diesel, synthetic lubricant (Mobil 0W40), used synthetic lubricant (used Mobil 0W40) and a biodegradable lubricant (Titan GT1) on Antarctic benthic microbial communities. Sediment from an uncontaminated site was collected, spiked with one of the oils and deployed in O'Brien Bay, East Antarctica. Sediment samples were then collected over $5 \mathrm{yr}$. All the oils caused changes in the microbial community in the top $1 \mathrm{~cm}$ of sediment, as determined by $16 \mathrm{~S}$ ribosomal ribonucleic acid (rRNA) gene-based terminal restriction fragment length polymorphism analysis. The greatest effect was observed in the SAB diesel treatment. The biodegradable oil did not have a significant effect on the communities initially, but the communities present at 2 and $5 \mathrm{yr}$ were significantly different to the controls. The unused and used lubricants were both significantly different to the control treatment. All the oils degraded, with $39 \%$ of the SAB, $15 \%$ of the unused lubricant, $15 \%$ of the used lubricant and $12 \%$ of the biodegradable oil, remaining after 5 yr. These results show that the effects of all these oils will be evident in the Antarctic benthic ecosystem for longer than $5 \mathrm{yr}$. This highlights the need for studies into the longevity and ecotoxicology of oil products in the Antarctic environment.
\end{abstract}

KEY WORDS: Biodegradable lubricant · Synthetic lubricant · Diesel $\cdot$ T-RFLP · Bacteria

\section{INTRODUCTION}

The fate and effect of petroleum products, particularly crude and refined fuel oils, on the marine environment are now reasonably well documented, thanks to studies triggered by large, high profile oil spills from tankers and oil production platforms (Kennicutt 1990, Braddock et al. 1995). Major spills have also occurred in polar regions, such as Alaska (the 'Exxon Valdez') and off the Antarctic Pensinsula ('Bahia Paraiso'). Both stimulated research on the environmental consequences of large-scale oil spills in cold regions (Kennicutt 1990). Although there is no doubt that large spills involving thousands of litres can be very destructive, small spills, of tens to hundreds of litres, occur much more frequently, are more widespread and may involve a greater range of products including lubricants (both petroleum based and synthetic), hydraulic and transmission oils as well as fuel oils. However, the environmental effects of these products, particularly synthetic lubricants, have not been well studied. The Antarctic environment, like other cold regions, may be more vulnerable to contaminants than temperate regions, particularly given the cold-induced slower rates of oil degradation (Poland et al. 2003). Several studies have shown decreased oil biodegradation (Brakstad \& Bonaunet 2006), even by Antarctic bacterial isolates (Michaud et al. 2004), and increased toxicity effects (Olsen et al. 2007) at lower temperatures. Although the presence of hydrocarbon-degrading micro-organisms is well known in Antarctic marine water (Delille \& Vaillant 1990, Yakimov et al. 2004), the long-term effects of diesels and lubricants on benthic communities are not well studied. Studies have been 
carried out to determine whether differences in Antarctic infaunal communities can be observed in contaminated sediments (e.g. Lenihan et al. 1990, Stark 2000), and these studies have found significant differences between faunal communities in non-impacted and hydrocarbon-impacted sediments. Previous work in the Casey region found that there were significant differences in the infaunal communities that were recruited to sediment contaminated with a mixture of diesel and lubricating oil (Stark et al. 2003).

In 2001 a 5 -yr project was initiated to investigate the effects and longevity of spills of Special Antarctic Blend (SAB) diesel and 3 lubricant oils in the Antarctic marine environment. Previous work had shown that differences in microbial, diatom and benthic infaunal communities developed when they were exposed to a mixture of SAB diesel and lubricant (Cunningham et al. 2003, Stark et al. 2003, Powell et al. 2005a). In the current project, sediment from a pristine site was subjected to one of 4 different treatments (addition of diesel or lubricant oils) before being incubated in situ in the Antarctic marine environment and then compared to clean sediments deployed at the same time (controls). Two of the oils are commonly used and spilled (see for example: Lenihan et al. 1990, Deprez et al. 1999) on Antarctic stations: SAB diesel fuel and a clean unused synthetic lubricant (Mobil 0W40). The Mobil 0W40 was also deployed as a treatment after use in a vehicle. Additionally, an alternative synthetic lubricant marketed as biodegradable (Titan GT1) was used as the fourth treatment. The initial (5 wk incubation) results from this experiment have been published previously (Powell et al. 2005b), and here we present the results obtained over $5 \mathrm{yr}$ of sampling. The information gained from this study is of practical value for selecting the type of oils which pose the least risk to the environment and for developing procedures for management and remediation of spills in sensitive areas. We expected that after $5 \mathrm{yr}$ the microbial communities in the SAB diesel, unused and used lubricant would have a greater resemblance to the control communities than they did at $5 \mathrm{wk}$, and that the community in the biodegradable oil would have remained similar to the control communities throughout the experimental deployment.

\section{MATERIALS AND METHODS}

Field methods. The site, set-up and sampling of this field experiment have been described in detail previously (Powell et al. 2005b, Thompson et al. 2006). Briefly, clean, uncontaminated sediment was collected from O'Brien Bay $\left(66^{\circ} 18^{\prime} \mathrm{S}, 110^{\circ} 32^{\prime} \mathrm{E}\right)$, near Casey station, sieved at $500 \mu \mathrm{m}$ to remove infauna and then spiked with one of 4 oils or left as a control. The treatments consisted of either $115 \mathrm{ml}$ of Titan GT1 (biodegradable lubricant), $115 \mathrm{ml}$ of Mobil 0W40 (unused lubricant), $115 \mathrm{ml}$ of used Mobil 0W40 (used lubricant) or $49 \mathrm{ml}$ of a mixture of $97 \% \mathrm{SAB}$ diesel with $3 \%$ squalene (SAB diesel) added to $35 \mathrm{l}$ of wet sediment. After settling for approximately $24 \mathrm{~h}$, the overlying water was removed, and the sediment was deployed in mesh-lined $(300 \mu \mathrm{m})$ trays $(600 \times 350 \times 100 \mathrm{~mm})$ by divers in a randomised block design in which each block was approximately $2 \mathrm{~m}$ apart. Four trays of each treatment were deployed for each planned sampling event.

Trays were collected after 5 wk (December 2001), 56 wk (December 2002), 65 wk (February 2003), 2 yr (November 2003) and $5 \mathrm{yr}$ (December 2006). The $65 \mathrm{wk}$ collection was included to allow a comparison of changes that occurred over a single summer (56 to $65 \mathrm{wk}$ ) and over a single winter ( $65 \mathrm{wk}$ to $2 \mathrm{yr}$ ). Capped cores were placed in trays by divers before being brought to the surface where the cores were removed from the trays, capped at the other end and labelled. Sediment samples were stored frozen at $-18^{\circ} \mathrm{C}$ until processing in Australia. Sediment cores were sliced, whilst still frozen, into $1 \mathrm{~cm}$ slices using a coping saw with sterile blades.

Total petroleum hydrocarbon (TPH) analysis. A homogenized subsample of approximately $5 \mathrm{~g}$ of sediment from the top $1 \mathrm{~cm}$ slice from each core was extracted overnight with $10 \mathrm{ml}$ of deionized water, $9 \mathrm{ml}$ of dichloromethane and $1 \mathrm{ml}$ of dichloromethane containing as internal standards (IS) $1 \mathrm{mg} \mathrm{l}^{-1}$ of cyclooctane, $1 \mathrm{mg} \mathrm{l}^{-1}$ of bromoeicosane, $0.25 \mathrm{mg} \mathrm{l}^{-1}$ of 1 , 4 -dichlorobenzene, $0.25 \mathrm{mg} \mathrm{l}^{-1}$ of deuterated tetracosane and $0.1 \mathrm{mg} \mathrm{l}^{-1} p$-terphenyl. The samples were centrifuged for $10 \mathrm{~min}$ at $1100 \times g$ at $10^{\circ} \mathrm{C}$ and the supernatant removed to a clean vial. The supernatants were analysed for total petroleum hydrocarbons (TPH) by gas chromatography-flame-ionization detector (GC-FID) on a Varian CP3800 (Varian) with a BP-1 (SGE) column ( $25 \mathrm{~m}$ i i.d. $0.22 \mathrm{~mm} ; 0.25 \mu \mathrm{m}$ film) and a Varian 8400 autosampler controlled with Star Chromatography Workstation. One microliter of extract was injected (1:20 split using a 1079 PTV injector) at $1.3 \mathrm{ml} \mathrm{min}^{-1}$. The detector flow rates were $29 \mathrm{ml} \mathrm{min}^{-1}$ for nitrogen, $30 \mathrm{ml} \mathrm{min}^{-1}$ for hydrogen and $300 \mathrm{ml} \mathrm{min}^{-1}$ for air. The oven temperature was initially $40^{\circ} \mathrm{C}$ held for $3 \mathrm{~min}$, then increased at a rate of $18^{\circ} \mathrm{C} \mathrm{min}{ }^{-1}$ to $330^{\circ} \mathrm{C}$ and held for a total run-time of $23 \mathrm{~min}$. The TPH concentrations were determined using calibration curves based on standards prepared with each of the oils at concentrations of approximately 8000, 5000, 2500, 1000, 500, $200,100,50$ and $0 \mathrm{mg} \mathrm{kg}^{-1}$. Using the IS response relative to the total detector response to all hydrocarbons, the TPH:IS ratio could be measured. This ratio was also 
calculated for the samples and used to determine the TPH values.

Terminal restriction fragment length polymorphism (T-RFLP) analysis. The $16 \mathrm{~S}$ ribosomal ribonucleic acid (rRNA) gene was targeted for T-RFLP analysis, as the genes involved in the degradation of the oils were too diverse to allow for the direct monitoring of degradation processes. DNA was extracted from $0.5 \mathrm{~g}$ of the top $1 \mathrm{~cm}$ slice using the PowerSoil DNA extraction kit (MoBio). The 16S rRNA gene was amplified using HotStar Plus (Qiagen) mastermix and $0.2 \mu \mathrm{M}$ of primers 10F (GAG TTT GAT CCT GGC TCA G) and 1492R (TAC GGY TAC CTT GTT ACG ACT T). 10F was labelled with WellRED dye D3 (SigmaProligo) on the 5' end. The thermal cycling program consisted of a $5 \mathrm{~min}$ initial denaturation step at $95^{\circ} \mathrm{C}$, followed by 35 cycles of $1 \mathrm{~min}$ at $94^{\circ} \mathrm{C}, 1 \mathrm{~min}$ at $55^{\circ} \mathrm{C}$ and $1 \mathrm{~min}$ at $72^{\circ} \mathrm{C}$; with a final step of $10 \mathrm{~min}$ at $72^{\circ} \mathrm{C}$. Two separate $\mathrm{PCR}$ reactions were pooled before digesting $15 \mu \mathrm{l}$ of the combined PCR product with $5 \mathrm{U}$ of either MspI, HaeIII or RsaI (New England Biolabs) for $5 \mathrm{~h}$. The digests were purified by ethanol precipitation into a 96-well plate. The purified digests were resuspended in $30 \mu \mathrm{l}$ of CEQ sample loading solution (Beckman Coulter) with $0.25 \mu \mathrm{l}$ of GenomeLab size standard 600 (Beckman Coulter). The fragments were separated on a Beckman Coulter CEQ Genetic Analysis system.

A list of fragment length and peak area was collated for each enzyme for each sample, excluding peaks with a height of less than 500 relative fluorescence units. Fragments that fell outside the range of the size standards (60 to $660 \mathrm{bp}$ ) were also excluded, as the size could not be accurately determined. As these peaks were excluded from all samples, the effect on the overall analysis was expected to be minimal. The peak area was then used to calculate the percentage peak area that each fragment contributed to the overall peak area for each sample. Fragments that made up less than $1 \%$ of the total peak area for a sample were given a value of zero, fragments with a peak area over $1 \%$ were left as a percentage (Sait et al. 2003). The T-Align program (http://inismor.ucd.ie/\%7Etalign/index.html; Smith et al. 2005) was used for each enzyme separately to compare fragment lengths between samples such that a matrix of peak area and fragment length was created. The data from the 3 enzymes were combined into 1 matrix such that the percentage peak area of each terminal restriction fragment (T-RF) length could be compared for all samples. Multivariate methods were used to analyse differences in the microbial communities using the Primer 6 package (Primer-E). Nonmetric multidimensional scaling (MDS) ordination plots were used to explore relationships between groups of samples on the basis of the strength of the similarities/dissimilarities between pairs of samples.
Tests of the null hypothesis of no difference between treatments were done using the Analysis of Similarity (ANOSIM) procedure in Primer 6 (Clarke 1993). A pvalue of less than 0.05 was considered to show a significant difference. However, where the number of replicates available meant that the smallest possible $\mathrm{p}$-value was greater than 0.05 , a result of this $p$-value was considered to be significantly different. The data were not transformed as the peak area had already been normalised to percentage peak area. The effect of each of the oils on the microbial community structure was assessed by comparing each treatment to the control at each sampling time individually and excluding data from any digest that was not available for both the control and treatment. The SIMPER procedure in Primer 6 was used to determine which T-RF were responsible for the differences between the control and each treatment group at each time point.

The diversity (S) of each sample was calculated by dividing the total number of T-RF by the number of successful restriction digests for that sample so that failed digests did not result in an artificially low diversity for any sample. The average diversity for each treatment/time-point group was then calculated.

\section{RESULTS}

\section{TPH concentrations}

The concentration of TPH in the top $1 \mathrm{~cm}$ of each of the treatments, including the control, is shown in Fig. 1. The sediment was deployed in 5 batches corresponding to the 5 collection times. The pre-deployment values ( $0 \mathrm{wk})$ are an average of the pre-deployment samples from all batches deployed. The control has a low concentration (50 to $450 \mathrm{mg} \mathrm{kg}^{-1}$ ) of naturally occurring organic matter in the TPH range at all time points. After $5 \mathrm{yr}$ the TPH concentration (mean $\pm \mathrm{SE}$, $\mathrm{n}=8$ ) in the surface layer of all the treatments is still significantly higher $(t$-test, $\mathrm{p}<0.05)$ than in the controls. The SAB treatment decreased from $2020( \pm 342)$ to $790( \pm 190) \mathrm{mg} \mathrm{kg}^{-1}$ over the $5 \mathrm{yr}$, a loss of $61 \%$. The unused lubricant (Mobil 0W40) decreased from 5740 $( \pm 1612)$ to $880( \pm 308) \mathrm{mg} \mathrm{kg}^{-1}(85 \%$ loss$)$; the used lubricant (used Mobil 0W40) decreased from 7095 $( \pm 3590)$ to $1045( \pm 450) \mathrm{mg} \mathrm{kg}^{-1}$ (85\% loss). The biodegradable oil (Titan GT1) decreased from 5539 ( \pm 762 ) to $658( \pm 182) \mathrm{mg} \mathrm{kg}^{-1}$, a loss of $88 \%$.

\section{Microbial community structure}

The diversity (S) of the microbial communities, based on the number of T-RF in each sample, is shown in 


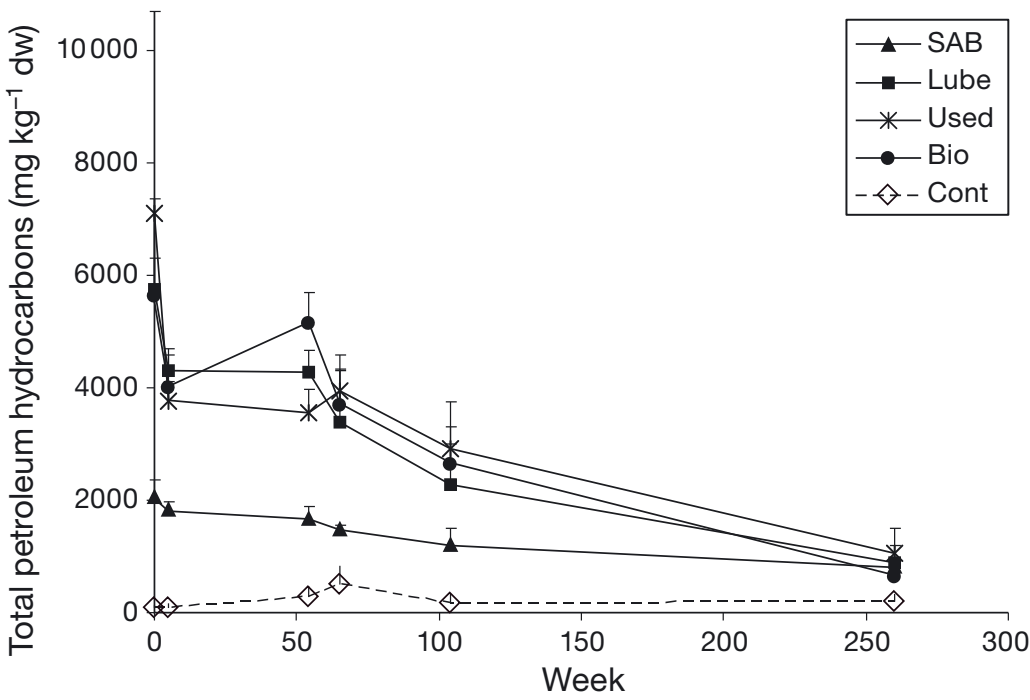

Fig. 1. TPH (mg kg-1 dry weight) in all treatments over 5 yr. Cont: control; SAB: SAB diesel; Lube: unused lubricant; Used: used lubricant; Bio: biodegradable lubricant. Error bars are standard error, $\mathrm{n}=8$ except for $0 \mathrm{wk}$ where $\mathrm{n}=10$ the SAB samples cluster at this time point, there is considerable variation within the control group, resulting in a non significant difference between the SAB and control treatments (Table 2, Fig. 2b). The biodegradable oil treatment exhibited a trend of increasing difference to the control over the $65 \mathrm{wk}$ to 5 yr sampling points (Table 2, Fig. 2).

The SIMPER procedure was used to determine which T-RF contributed most to the difference between the microbial communities in the control and the treatments. For some of the comparisons the difference was primarily due to the appearance of T-RF in the control that were not present in the treatment; however, for other comparisons, T-RF were present in the treatment but not the control (data not shown). No consistent pattern could be observed.
Table 1 for each treatment at each time point. The diversity did not vary significantly between the control and treatments or with time. The only comparisons which produced significant p-values were the difference between the communities in the control sediment at $65 \mathrm{wk}$ and $2 \mathrm{yr}$ and between the communities in the control and biodegradable oil treatment at both 5 and $65 \mathrm{wk}$.

The differences between all treatments and control are shown (separately for each time point) in Fig. 2 as MDS plots. After $5 \mathrm{wk}$, microbial communities in the used lubricant treatment (Mobil 0W40) were significantly different from the control and remained so at all time points except for the 2 yr time point (Table 2, Fig. 2). The unused lubricant was different from the control at all time points except for the 2 yr time point, where it exhibited large variation and with one sample having a greater similarity to the controls than the others (Table 2, Fig. 2d). The SAB diesel treatment was different at all time points except at 56 wk. Although

Table 1. Average diversity (standard deviation) of microbial communities in sediment measured as the number of different terminal restriction fragments present in one restriction digest. $\mathrm{n}=4$

\begin{tabular}{|lccccc|}
\hline & 5 wk & 56 wk & 65 wk & 2 yr & 5 yr \\
\hline Control & $25(3)$ & $28(2)$ & $24(2)$ & $30(2)$ & $24(6)$ \\
Biodegradable oil & $32(4)$ & $27(5)$ & $32(1)$ & $27(3)$ & $30(1)$ \\
Lubricant & $27(3)$ & $27(2)$ & $30(3)$ & $25(4)$ & $32(2)$ \\
Used lubricant & $29(3)$ & $30(2)$ & $26(5)$ & $31(1)$ & $34(3)$ \\
SAB diesel & $30(5)$ & $26(2)$ & $24(4)$ & $32(5)$ & $27(9)$ \\
\hline
\end{tabular}

\section{Temporal changes in each treatment}

The change in the microbial community structure over time is shown separately for each treatment in Fig. 3. Communities in the control samples exhibited the greatest amount of change through time. Out of the
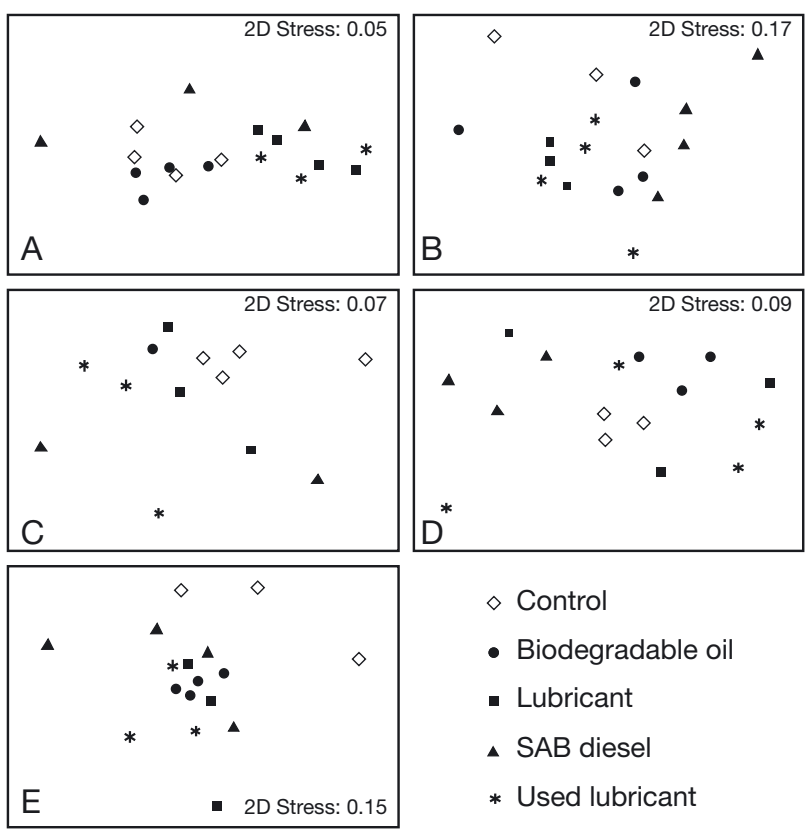

Fig. 2. MDS representing the microbial community structure at each time point over $5 \mathrm{yr}$. Symbols for treatments remain the same for each time point. $\mathrm{A}=5 \mathrm{wk}, \mathrm{B}=56 \mathrm{wk}, \mathrm{C}=65 \mathrm{wk}$,

$$
\mathrm{D}=2 \mathrm{yr}, \mathrm{E}=5 \mathrm{yr}
$$


Table 2. Comparison of microbial community structure between the control and treatments and all time intervals. ANOSIM R statistic ( $p$-value) is shown. Bold = significantly different; $\mathrm{n}$ varies depending upon number of successful restriction digests (see 'Materials and methods')

\begin{tabular}{|c|c|c|c|c|c|}
\hline \multirow{2}{*}{ Treatment } & \multirow[b]{2}{*}{$\begin{array}{l}5 \mathrm{wk} \\
\mathrm{n}=4\end{array}$} & \multirow[b]{2}{*}{$\begin{array}{c}56 \text { wk } \\
\text { Cor } \\
\text { control } n=3, \\
\text { other } \mathrm{n}=4\end{array}$} & \multirow[b]{2}{*}{$\begin{array}{l}\text { ntrol vs. treatm } \\
65 \text { wk } \\
\text { control } \mathrm{n}=4 \\
\text { other } \mathrm{n}=3\end{array}$} & \multirow[b]{2}{*}{$\begin{array}{l}2 \mathrm{yr} \\
\mathrm{n}=4\end{array}$} & \multirow[b]{2}{*}{$\begin{array}{c}5 \mathrm{yr} \\
\text { used, } \\
\text { unused } \mathrm{n}=3 \text {, } \\
\text { other } \mathrm{n}=4\end{array}$} \\
\hline & & & & & \\
\hline Biodegradable oil & $\begin{array}{c}-0.104 \\
(0.60)\end{array}$ & $\begin{array}{c}-0.074 \\
(0.60)\end{array}$ & $\begin{array}{c}0.352 \\
(0.086)\end{array}$ & $\begin{array}{c}0.593 \\
(0.057)\end{array}$ & $\begin{array}{c}0.593 \\
(0.029)\end{array}$ \\
\hline Unused lubricant & $\begin{array}{c}0.833 \\
(0.029)\end{array}$ & $\begin{array}{c}0.63 \\
(0.10)\end{array}$ & $\begin{array}{c}0.648 \\
(0.057)\end{array}$ & $\begin{array}{l}0.019 \\
(0.37)\end{array}$ & $\begin{array}{l}0.333 \\
(0.10)\end{array}$ \\
\hline SAB diesel & $\begin{array}{c}0.407 \\
(0.029)\end{array}$ & $\begin{array}{c}0.222 \\
(0.14)\end{array}$ & $\begin{array}{c}0.593 \\
(0.029)\end{array}$ & $\begin{array}{c}0.889 \\
(0.029)\end{array}$ & $\begin{array}{c}0.389 \\
(0.057)\end{array}$ \\
\hline Used lubricant & $\begin{array}{c}0.722 \\
(0.029)\end{array}$ & $\begin{array}{c}0.315 \\
(0.057)\end{array}$ & $\begin{array}{c}0.741 \\
(0.029)\end{array}$ & $\begin{array}{c}0.481 \\
(0.086)\end{array}$ & $\begin{array}{c}0.593 \\
(0.10)\end{array}$ \\
\hline
\end{tabular}

summer interval. Of the lubricant treatments, the biodegradable oil treatment showed the same number of differences between times as the control but did not change over the single summer (56 to $65 \mathrm{wk}$ ) period. The other lubricant treatments changed very little over time, with only 3 significant differences between the time intervals for each (Table 3). The pattern observed for the SAB treatments was different again (Fig. 3), with the greatest difference early in the experiment. The 5 wk samples were significantly different to the other time points, but there were no significant differences among the other time points (Table 3).
10 comparisons between time points, 8 were significantly different, with the greatest differences (highest $R$ values) being comparisons with the $65 \mathrm{wk}$ time point (Table 3). It is worth noting that the $65 \mathrm{wk}$ samples were collected in February (late summer) instead of December (late spring/early summer), and this may represent a seasonal effect on microbial communities over summer. The control treatment was the only community to show any change over the 56 to $65 \mathrm{wk}$ single
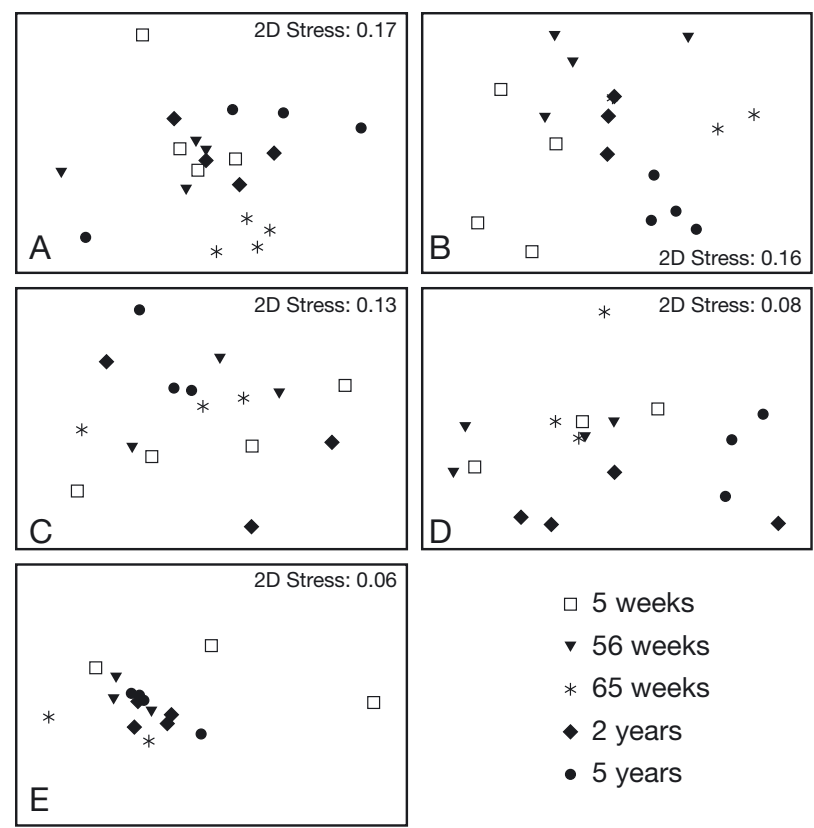

$\square 5$ weeks

- 56 weeks

* 65 weeks

- 2 years

- 5 years

Fig. 3. MDS representing the microbial community structure for each treatment at each time point over 5 yr. Symbols for time points remain the same for each treatment. $\mathrm{A}=$ control $_{\text {, }}$ $\mathrm{B}=$ biodegradable oil, $\mathrm{C}=$ lubricant, $\mathrm{D}=$ used lubricant, $\mathrm{E}=\mathrm{SAB}$ diesel

\section{Relationship between microbial community structure and oil concentrations}

The relationship between the changes in the microbial communities and the sediment oil concentration was examined by determining the Spearman rank correlation coefficient between the ANOSIM R value, a measure of the dissimilarity of the microbial communities between the control and each treatment, and the $\mathrm{TPH}$ levels. As the microbial communities in the predeployment samples were not significantly different from the control (Powell et al. 2005b), we assumed values of $0 \mathrm{mg} \mathrm{kg}^{-1} \mathrm{TPH}$ and an $\mathrm{R}$ value of 0 for the predeployment sediments. There was a correlation of 0.972 for the unused lubricant (Mobil 0W40), 0.945 for the used lubricant (used Mobil 0W40), 0.834 for the $\mathrm{SAB}$ and -0.240 for the biodegradable oil (Titan GT1). The positive correlations indicate that as the TPH decreased, $\mathrm{R}$ decreased, i.e. the microbial communities in the sediment exposed to the oil became more like the control. Thus, the communities in the unused oil treatment showed the greatest shift towards the control treatment communities over this experiment. The negative correlation for the biodegradable oil treatment indicates that as the TPH decreased, R increased and the microbial communities became less like the control communities.

\section{DISCUSSION}

\section{Loss of oils from deployed sediment}

Over the $5 \mathrm{yr}$ of this experiment between 60 and $88 \%$ of the oils were lost from the top $1 \mathrm{~cm}$ of the sediment. However, the amount of oil remaining in 
Table 3. ANOSIM results for comparison of microbial community structure within each treatment over time. Total $=$ total number of significant differences between sampling intervals. $\mathrm{n}=4$ except for $2 \mathrm{yr}$ for the biodegradable treatment, $56 \mathrm{wk}, 2$ and $5 \mathrm{yr}$ for the unused lubricant, $5 \mathrm{wk}$ and $5 \mathrm{yr}$ for the used lubricant and $5 \mathrm{wk}$ and $2 \mathrm{yr}$ for the SAB diesel for which $\mathrm{n}=3$, as samples lacking some digest data were excluded from the analysis. $\mathrm{S}=$ summer, $\mathrm{W}=$ winter. Bold = significantly different

\begin{tabular}{|c|c|c|c|c|c|c|c|c|c|c|c|}
\hline \multirow[t]{2}{*}{ Time interval } & \multirow[t]{2}{*}{ Season } & \multicolumn{2}{|c|}{ Control } & \multicolumn{2}{|c|}{ Biodegradable } & \multicolumn{2}{|c|}{ Unused lubricant } & \multicolumn{2}{|c|}{ Used lubricant } & \multicolumn{2}{|c|}{ SAB diesel } \\
\hline & & $\mathrm{R}$ & $\mathrm{p}$ & $\mathrm{R}$ & $\mathrm{p}$ & $\mathrm{R}$ & $\mathrm{p}$ & $\mathrm{R}$ & $\mathrm{p}$ & $\mathrm{R}$ & $\mathrm{p}$ \\
\hline 56 to $65 \mathrm{wk}$ & $\mathrm{S}$ & 0.677 & 0.029 & 0.278 & 0.17 & -0.185 & 0.90 & -0.074 & 0.65 & 0.222 & 0.14 \\
\hline $65 \mathrm{wk}$ to $2 \mathrm{yr}$ & W & 0.188 & 0.086 & 0.481 & 0.10 & -0.148 & 0.80 & 0.074 & 0.40 & 0.148 & 0.40 \\
\hline 5 to $56 \mathrm{wk}$ & SW & 0.167 & 0.029 & 0.323 & 0.057 & -0.074 & 0.51 & -0.167 & 0.80 & 0.593 & 0.029 \\
\hline $56 \mathrm{wk}$ to $2 \mathrm{yr}$ & SW & 0.031 & 0.370 & 0.852 & 0.057 & 0.148 & 0.40 & 0.115 & 0.25 & 0.296 & 0.30 \\
\hline 5 to $65 \mathrm{wk}$ & SWS & 0.865 & 0.029 & 0.556 & 0.029 & 0.001 & 0.45 & -0.037 & 0.70 & 0.296 & 0.20 \\
\hline $5 \mathrm{wk}$ to $2 \mathrm{yr}$ & SWS & 0.583 & 0.029 & 1.00 & 0.029 & 0.001 & 0.54 & -0.019 & 0.51 & 0.444 & 0.10 \\
\hline 2 to $5 \mathrm{yr}$ & SWSWSW & 0.444 & 0.029 & 0.444 & 0.086 & 0.333 & 0.20 & 0.407 & 0.086 & -0.111 & 0.68 \\
\hline $65 \mathrm{wk}$ to $5 \mathrm{yr}$ & WSWSWSW & 0.759 & 0.029 & 0.833 & 0.029 & 0.148 & 0.20 & 0.963 & 0.10 & 0.321 & 0.26 \\
\hline $56 \mathrm{wk}$ to $5 \mathrm{yr}$ & SWSWSWSW & 0.315 & 0.057 & 0.49 & 0.057 & 0.37 & 0.10 & 0.741 & 0.057 & 0.204 & 0.11 \\
\hline $5 \mathrm{wk}$ to $5 \mathrm{yr}$ & SWSWSWSWSW & 0.444 & 0.057 & 0.917 & 0.029 & 0.296 & 0.14 & 0.667 & 0.10 & 0.352 & 0.029 \\
\hline \multicolumn{2}{|c|}{ Total number of significant differences } & \multicolumn{2}{|c|}{8} & \multicolumn{2}{|c|}{8} & \multicolumn{2}{|c|}{3} & \multicolumn{2}{|c|}{3} & \multicolumn{2}{|c|}{3} \\
\hline
\end{tabular}

the sediment after $5 \mathrm{yr}$ was still significantly higher than in the control $(\mathrm{p}<0.05)$. Oils can be very persistent in sediment; $27 \mathrm{yr}$ after an oil spill in a temperate salt marsh (Buzzards Bay, Massachusetts), TPH values of up to $8000 \mathrm{mg} \mathrm{kg}^{-1}$ were still measured in the sediment (Peacock et al. 2007). Other studies have found that although the oil persists in the sediment, the toxicity decreases within 2 yr (Page et al. 2002, Jonker et al. 2006) because of weathering of toxic components of the oil. Our study supports the idea that even though significant amounts of oil persist in marine sediments after a spill, its toxicity will decrease, as evidenced by the increasing similarity between control and oil treatments as the TPH decreases.

Some of the decrease in amount of oil in the sediments in our experiment can be attributed to the deployment process; Thompson et al. (2006) found that up to $20 \%$ of the oils were lost during tray deployment. Most of this loss occurred as fine particulates and nonaqueous phase droplets, both of which drifted from the sediment as the trays were lowered to the seabed. Thus, at least some of the decrease in TPH concentrations observed in the first $5 \mathrm{wk}$ (Fig. 1) is due to physical loss and not biodegradation. Further evidence of this is that Thompson et al. (2006) observed an equal loss of different classes of compounds in the oils. When biodegradation is the main route of loss of oil, easily degraded compounds are seen to decrease first (Snape et al. 2005).

For all the treatments, the decrease in TPH in the first year (between 5 and $56 \mathrm{wk}$ ) is negligible $(<10 \%)$, and the most loss occurs from 65 wk to 2 and 5 yr. The time interval between the 5 and 56 wk sampling included the first winter exposure for the experiment. It is unclear whether this is a lag period as the microbial communities adapt to the presence of the oil, or whether it is a normal period of decreased metabolic activity in the sediment, or a combination of both. Seasonal effects in benthic microbial communities have been shown to be variable (Trimmer et al. 1997). An experiment over a similar time period, in sediment from a tidal flat in the Netherlands (Jonker et al. 2006), found that after 14 to 19 mo of weathering, a distillate marine grade diesel became less toxic concurrent with a decrease to approximately $20 \%$ of the original concentration. In our study, most of the TPH loss occurred within $2 \mathrm{yr}$, with a decrease of approximately $750 \mathrm{mg}$ $\mathrm{kg}^{-1}$ (to $40 \%$ of the original concentration), whereas the loss between 2 yr and 5 yr was approximately $400 \mathrm{mg} \mathrm{kg}^{-1}$ (a loss of an extra $20 \%$ of the original concentration).

Measuring hydrocarbon and oil concentrations by $\mathrm{TPH}$ methods gives an estimate of the amount of oil present; however, it does not provide any information on whether the loss is biological or physical. Biodegradation indices (ratio of easily degraded to more recalcitrant components) are the best indication of this (Snape et al. 2005). Either way, the breakdown products may be either more or less toxic than the original compounds. Mineralisation to carbon dioxide and water produces non-toxic products, but increased toxicity during the degradation process has been observed in some studies (Ramirez et al. 1996, Chaineau et al. 2003). More detailed chemical analysis of these samples is being undertaken to elucidate important processes and potential degradation products and pathways. 


\section{Effect of oils}

Comparison of samples of the collected clean sediment (prior to treatment) with samples taken prior to deployment showed that the process of experimental setup did not significantly alter the microbial community in numbers of bacteria or the community structure as measured by denaturing gradient gel electrophoresis (Powell et al. 2005b), indicating that the microbial communities in the deployed sediment are representative of the naturally occurring communities. The results of analyses carried out on samples collected after $5 \mathrm{wk}$ in situ incubation showed significant differences in the microbial communities that were present in the SAB diesel and unused and used lubricant treatments compared to the control. However, the microbial community in the biodegradable oil treatment was not different to the control after 5 wk (Powell et al. 2005b). In contrast, analysis of the infaunal communities (Thompson et al. 2007) revealed significant differences in the community structure of the control compared to the unused, used and biodegradable lubricants after $5 \mathrm{wk}$ and $1 \mathrm{yr}$.

After the collection of the 5 yr samples, all time points were subjected to analysis of the microbial community structure using T-RFLP. The analysis of which T-RF contributed most to the differences between the groups showed that in some cases the appearance of T$\mathrm{RF}$ in the control contributed most to the differences, and in some cases the appearance of T-RF in the treatments contributed the most. As the overall diversity (number of T-RF) was generally stable, this suggests that the differences between treatment groups are due to changes in which part of the microbial community is dominant and does not represent dramatic changes in the presence or absence of specific taxa.

The microbial community structure in the control treatment changed significantly throughout the experiment (8 out of the possible 10 comparisons significantly different, Table 3). These changes in the control communities are evidence that there is dynamic variation in natural microbial communities over time, possibly due to seasonal effects such as ice-cover (and hence light levels) and nutrient availability influencing growth rates and community structure. Strong seasonal effects have been observed in benthic microbial communities previously, both in the Antarctic (Delille 1995, Clarke \& Leakey 1996) and in temperate regions (Findlay \& Watling 1998). In the current study, the microbial communities in the SAB diesel, unused and used lubricant treatments changed minimally over the course of the experiment ( 3 of the possible 10 comparisons were significantly different; Table 3). The high degree of similarity between the communities in the oil treatment at different times, as opposed to the varia- tion seen in the controls, is further evidence that the greatest influence on the microbial community structure in these treatments is the presence of the oils. Thus, one of the effects of oil in sediment is to damp down or reduce seasonal changes in microbial community structure.

The biodegradable oil varies in a similar manner to the control, suggesting, at least initially, that the biodegradable oil did not have as strong an effect on the microbial community as the other oils, possibly because the esters present in this oil were being used as a carbon source by the bacteria that were already numerous in the microbial community. Little work has been carried out on the biodegradation of this class of oils, but there is evidence that esterases, which are common in many bacterial species, are involved (Wright et al. 1993). Degradation of esters and ester bonds has been reported previously in Comamonas (Godocikova et al. 2004) and Micrococcus (Wright et al. 1993) species. As time progressed, the microbial communities became more different to the control, as evidenced by the negative correlation between the ANOSIM R value and TPH levels, and at the 2 and $5 \mathrm{yr}$ time points the microbial community was significantly different to that in the control. This may be because the easily degraded esters had been lost from the sediment either through biodegradation or abiotic processes, and bacteria which were able to degrade other components were more abundant. Alternatively, this may be a response to the accumulation of toxic metabolites with species more tolerant of these compounds increasing in number.

The SAB diesel treatment initially had the strongest effect on the microbial communities (Powell et al. 2005b). The total numbers of bacteria and the numbers of SAB-degrading bacteria increased significantly, and the microbial community structure in this treatment was the most different to the control after $5 \mathrm{wk}$ (Powell et al. 2005b). In Table 3, it can be seen that comparisons of the $5 \mathrm{wk}$ samples to samples at other time points were generally significantly different, whereas comparisons between other time points were not significantly different. In other words, the microbial community present after $5 \mathrm{wk}$ is unique. It may be that at 5 wk the community was dominated by microbes able to utilise the easily degraded components of the SAB such as the alkanes. During the first $56 \mathrm{wk}$, the alkanes decreased significantly (E. N. M. Woolfenden unpubl. data), and it is possible the community structure changed as other degrading organisms, such as those able to degrade aromatics, became more numerous. The correlation coefficient between the ANOSIM R value and TPH levels also indicates that at as time passed the SAB treatment community was becoming more like the community in the control sediment. 
There was little difference between the microbial community structure in the unused and used lubricant (Mobil 0W40) treatments or in the way that these communities changed through time. Initially, both caused a decrease in the number of bacteria present in the sediment, and both had a significant effect on the microbial community structure after 5 wk (Powell et al. 2005b). The decrease in bacterial numbers suggests that the communities were not using the lubricant as a carbon source but were responding to toxic chemicals with a change in the ratio of susceptible species to tolerant species. At most time intervals, the unused and used lubricants cluster together (Fig. 2), with the greatest difference between the unused and the used treatments after $5 \mathrm{yr}$. As with the SAB diesel treatment, the similarity of the communities within these treatments throughout the experiment indicates that the presence of the oils has a greater effect on the microbial communities than other environmental variables. Correlation coefficients between the ANOSIM R and TPH values for the unused and used lubricant show that as the TPH levels decreased, so did the difference between the treatment and control groups. Longer deployment would be needed to determine whether this trend would continue and whether the communities would adapt to the oils and use them as a carbon source. Alternatively, this trend may be due to the loss of toxic components of the oil, allowing more sensitive species to start increasing in number again.

\section{CONCLUSIONS}

Degradation of all the oils was observed in the top $1 \mathrm{~cm}$ of the sediment, with the greatest loss from the biodegradable lubricant treatment (88\%). Despite this, the sediment from all treatments, including the biodegradable Titan GT1, still contained significantly higher TPH than the control sediment. These results are for the top layer of the sediment, generally regarded as the most biologically active region in the sediment profile. Analyses of sediment profiles are still required to assess the effects at different depths in the sediment profile and whether the microbial communities deeper in the sediment are able to degrade the oils. As TPH values do not provide any information about breakdown products, we do not know whether the degradation of these oils is producing compounds that are more or less toxic than the original oil. There is some evidence that the biodegradable oil may be becoming more toxic as degradation proceeds. More detailed chemical analysis will provide clues as to the fate of these oils in the Antarctic marine environment. While this oil may be marketed as being highly biodegradable and less toxic than conventional lubri- cants, it appears that this may be only a short-term effect and there may be long-term implications related to its degradation and an increase in its toxicity.

This study was initiated as a long-term study, and it was expected that after 5 yr the benthic communities in hydrocarbon treatments would begin to resemble their undisturbed state. It is now clear that the effects of fuel or oil spills in the Antarctic marine environment will be evident for much longer than 5 yr. This effect is likely to be even greater deeper in the sediment where oil concentrations may be much higher than in the surface layer. Much longer studies are required to understand the long-term effects of these products and their eventual fate.

Acknowledgements. This work was supported by Australian Antarctic Science grants 2201, 2672 and 1163. The authors thank the many members of the Casey dive teams for their efforts over the $5 \mathrm{yr}$ of this project.

\section{LITERATURE CITED}

Braddock JF, Lindstrom JE, Brown EJ (1995) Distribution of hydrocarbon degrading microorganisms from Prince William Sound, Alaska, following the Exxon Valdez oil spill. Mar Pollut Bull 30:125-132

$>$ Brakstad OG, Bonaunet K (2006) Biodegradation of petroleum hydrocarbons in seawater at low temperatures $(0-5$ degrees C) and bacterial communities associated with degradation. Biodegradation 17:71-82

> Chaineau CH, Yepremian C, Vidalie JF, Ducreux J, Ballerini D (2003) Bioremediation of a crude oil-polluted soil: biodegradation, leaching and toxicity assessments. Water Air Soil Pollut 144:419-440

Clarke KR (1993) Non-parametric multivariate analyses of changes in community structure. Aust J Ecol 18:117-143

Clarke A, Leakey RJG (1996) The seasonal cycle of phytoplankton, macronutrients, and the microbial community in a nearshore Antarctic marine ecosystem. Limnol Oceanogr 41:1281-1294

Cunningham L, Stark JS, Snape I, McMinn A, Riddle MJ (2003) Effects of metal and petroleum hydrocarbon contamination on benthic diatom communities near Casey Station, Antarctica: an experimental approach. J Phycol 39: 490-503

Delille D (1995) Seasonal-changes of sub-antarctic benthic bacterial communities. Hydrobiologia 310:47-57

Delille D, Vaillant N (1990) The influence of crude oil on the growth of subantarctic marine bacteria. Antarct Sci 2: 123-127

Deprez PP, Arens M, Locher H (1999) Identification and assessment of contaminated sites at Casey Station, Wilkes Land, Antarctica. Polar Rec 35:299-316

Findlay RH, Watling L (1998) Seasonal variation in the structure of a marine benthic microbial community. Microb Ecol 36:23-30

Godocikova J, Ferianc P, Polek B (2004) Lag period of ${ }^{14} \mathrm{CO}_{2}$ evolution from dioctyl sulpho[2,3- $\left.{ }^{14} \mathrm{C}\right]$ succinate in relation to adaptation of bacterium, Comamonas terrigena, to dialkyl esters of sulphosuccinate. Biotechnol Lett 26:1497-1500

> Jonker MTO, Brils JM, Sinke AJC, Murk AJ, Koelmans AA (2006) Weathering and toxicity of marine sediments cont- 
aminated with oils and polycyclic aromatic hydrocarbons. Environ Toxicol Chem 25:1345-1353

Kennicutt M II (1990) Oil spillage in Antarctica: initial report of the National Science Foundation-sponsored Quick Response Team on the grounding of the Bahia Paraiso. Environ Sci Technol 24:620-624

Lenihan HS, Oliver JS, Oakden JM, Stephenson MD (1990) Intense and localized benthic marine pollution around McMurdo Station, Antarctica. Mar Pollut Bull 21:422-430

Michaud L, Lo Giudice A, Saitta M, De Domenico M, Bruni V (2004) The biodegradation efficiency on diesel oil by two psychrotrophic Antarctic marine bacteria during a twomonth-long experiment. Mar Pollut Bull 49:405-409

> Olsen GH, Carroll ML, Renaud PE, Ambrose WG, Olsson R, Carroll J (2007) Benthic community response to petroleum-associated components in Arctic versus temperate marine sediments. Mar Biol 151:2167-2176

Page DS, Boehm PD, Stubblefield WA, Parker KR, Gilfillan ES, Neff JM, Maki AW (2002) Hydrocarbon composition and toxicity of sediments following the Exxon Valdez oil spill in Prince William Sound, Alaska, USA. Environ Toxicol Chem 21:1438-1450

Peacock EE, Hampson GR, Nelson RK, Xu L and others (2007) The 1974 spill of the Bouchard 65 oil barge: Petroleum hydrocarbons persist in Winsor Cove salt marsh sediments. Mar Pollut Bull 54:214-225

Poland JS, Riddle MJ, Zeeb BA (2003) Contaminants in the Arctic and the Antarctic: a comparison of sources, impacts, and remediation options. Polar Rec 39:369-383

Powell SM, Riddle MJ, Snape I, Stark JS (2005a) Location and DGGE methodology can influence interpretation of field experimental studies on the response to hydrocarbons by Antarctic benthic microbial community. Antarct Sci $17: 353-360$

Powell SM, Snape I, Bowman JP, Thompson BAW, Stark JS, McCammon SA, Riddle MJ (2005b) A comparison of the short term effects of diesel fuel and lubricant oils on Antarctic benthic microbial communities. J Exp Mar Biol Ecol 322:53-65

Ramirez NE, Vargas MC, Sanchez FN (1996) Use of the 'Sediment-Chromotest' for monitoring stimulated hydrocarbon biodegradation processes. Environ Toxicol Water Qual 11: $223-230$

Editorial responsibility: Josep Gasol,

Barcelona, Spain
Sait L, Galic M, Strugnell RA, Janssen PH (2003) Secretory antibodies do not affect the composition of the bacterial microbiota in the terminal ileum of 10-week-old mice. Appl Environ Microbiol 69:2100-2109

> Smith CJ, Danilowicz BS, Clear AK, Costello FJ, Wilson B, Meijer WG (2005) T-Align, a web-based tool for comparison of multiple terminal restriction fragment length polymorphism profiles. FEMS Microbiol Ecol 54:375-380

Snape I, Harvey PMA, Ferguson SH, Rayner JL, Revill AT (2005) Investigation of evaporation and biodegradation of fuel spills in Antarctica I. A chemical approach using GC-FID. Chemosphere 61:1485-1494

> Stark JS (2000) The distribution and abundance of soft-sediment macrobenthos around Casey Station, East Antarctica. Polar Biol 23:840-850

> Stark JS, Snape I, Riddle MJ (2003) The effects of petroleum hydrocarbons and heavy metal contamination of marine sediments on recruitment of Antarctic soft-sediment assemblages: a field experimental investigation. J Exp Mar Biol Ecol 283:21-50

> Thompson BAW, Davies NW, Goldsworthy PM, Riddle MJ, Snape I, Stark JS (2006) In situ lubricant degradation in Antarctic marine sediments. 1. Short-term changes. Environ Toxicol Chem 25:356-366

> Thompson BAW, Goldsworthy PM, Riddle MJ, Snape I, Stark JS (2007) Contamination effects by a 'conventional' and a 'biodegradable' lubricant oil on infaunal recruitment to Antarctic sediments: a field experiment. J Exp Mar Biol Ecol 340:213-226

Trimmer M, Purdy KJ, Nedwell DB (1997) Process measurement and phylogenetic analysis of the sulfate reducing bacterial communities of two contrasting benthic sites in the upper estuary of the Great Ouse, Norfolk, UK. FEMS Microbiol Ecol 24:333-342

Wright MA, Taylor F, Randles SJ, Brown DE, Higgins IJ (1993) Biodegradation of a synthetic lubricant by Micrococcus roseus. Appl Environ Microbiol 59:1072-1076

Yakimov MM, Gentile G, Bruni V, Cappello S, D'Auria G, Golyshin PN, Giuliano L (2004) Crude oil-induced structural shift of coastal bacterial communities of rod bay (Terra Nova Bay, Ross Sea, Antarctica) and characterization of cultured cold-adapted hydrocarbonoclastic bacteria. FEMS Microbiol Ecol 49:419-432

Submitted: March 23, 2010; Accepted: July 27, 2010

Proofs received from author(s): August 27, 2010 